\title{
Overview of packaging materials for Dairy packaging
}

\author{
Irena Barukčić, Mario Ščetar*, Katarina Lisak Jakopović, Mia Kurek, Rajka Božanić, Kata Galić \\ Faculty of Food Technology and Biotechnology, University of Zagreb, Pierottijeva 6, HR-10000 Zagreb, Croatia
}

*Corresponding author: mscetar@pbf.hr

\begin{abstract}
Regarding milk producing, it is well known that processing and packaging are the two equally important operational phases. Packaging is the last, but definetly not the less important phase. Various automation strategies are constantly being utilized in every phase of processing, packaging and production/use of new packaging materials.

The most suitable packaging will provide adequate properties to pack liquid milk and dairy products which have an important role to prolonged product shelf life. Temperature and moisture are important parameters which affect the shelf life of packaged milk and dairy products, due to their effect on the bacterial growth especially in fermented milk products.

The aim of this review article is to introduce advantages and disadvantages and principles of packaging methods and materials correlated to shelflife of dairy products.
\end{abstract}

Keywords: milk, dairy products, shelf life, packaging

\section{Sažetak}

Kod proizvodnje mlijeka, poznato je da su prerada i pakiranje dvije podjednako važne operativne faze. Pakiranje je posljednja, ali ne i manje važna faza. Različite strategije automatizacije stalno se koriste u svakoj fazi obrade, pakiranja i proizvodnje/uporabe novih ambalažnih materijala. Najprikladnija ambalaža će pružiti odgovarajuća svojstva za pakiranje tekućeg mlijeka i mliječnih proizvoda a koji imaju važnu ulogu u produljenju roka trajnosti proizvoda. Temperatura i vlaga važni su parametri koji utječu na rok trajanja pakiranog mlijeka i mliječnih proizvoda, zbog njihovog utjecaja na rast bakterija, posebno u fermentiranim mliječnim proizvodima.

Cilj ovog preglednog članka je opisati prednosti i nedostatke te načela metoda i materijala pakiranja u korelaciji s rokom trajanja mliječnih proizvoda.

Ključne riječi: mlijeko, mliječni proizvodi, rok trajnosti, ambalaža

\section{Introduction}

Today, lots of preservation techniques are available to extend the shelf storage of food products, among which packaging is a very important. The packaging process has several basic roles, i.e. protect the food from the environmental influence, preventing/reducing microbial growth, stop or retard deterioration of food quality. Nowadays, food packaging not only targets convenience and protection properties, but also presents many other functions such as communication, enabling handling, marketing and ergonomics (Khoshgozaran et al. 2012; Alizadeh et al., 2020).

The manufacturing process of dairy products is quite sophisticated, however there are various seminal factors influencing the textural and rheological properties of the products: milk fat content, milk proteins, thickener type, heat treatment, incubation temperature, rate of acidification, and stabilizers content. Thus, optimized amounts of ingredients with their quality level, cutting time, and safety-assurance can be determined non-invasively and non-destructively in the production line.

Therefore, the final yield of the manufacturing process is affected by different parameters such as the characteristics of the products, duration of processes, number of processes, type and quality of additives and ingredients, and packaging conditions (Mohammadi et al. 2017).

As the last stage of production, packaging is an integral and essential component of the value chain of food and beverages, from the stage of production to the stage of consumption, and supports sustainable and sustainable food supply chains. This review article aims to illustrate the key role of packaging in the daily supply chain of dairy products and in the daily lives of consumers. By the all dairy products on the market today, the focus is on packaging materials for milk and dairy products while ensuring functionality and extending the shelf-life of food products such as milk, fermented milk products, butter, cheese, dehidrated dairy products and ice cream. 


\section{Deterioration of milk and dairy products}

From chemical aspect, milk is as a colloidal suspension consisting of protein micelles and fat globules dispersed in a continuous serum phase containing mostly water, salts, lactose and whey proteins (Lopez, Corredig, \& Alexander, 2009).

Shelf life of milk and milk products is limited because of their high aw, favourable $\mathrm{pH}$ and presence of macro- and micronutrients that favour the growth of spoilage and pathogen microbs (Muir 1996 a,b,c). Rapid spoilage could adversely affect flavour, texture and visually obsevable colour changes of refrigerated raw or pasteurised milk, cottage cheese and similar products. Psychrotrophic bacteria species, such as Pseudomonas, Bacillus, Micrococcus, Aerococcus, and Lactococcus as well as the family Enterobacteriaceaes, usually account for $90 \%$ or even more of the total microbes present in the cooled raw milk. Non-psychrortophic strains of lactic acid bacteria, yeasts and moulds are also present but in smaller proportions (Boor and Murphy, 2002; Chambers, 2002; Ledenbach and Marshall, 2009; Samaržija et al., 2012). Additionally to their ability to survive and to multiply at cold storage temperatures, psychrotrophic bacteria produce heat resistant hydrolytic enzymes which keep their activity even after conventionally used heat treatments in the dairy industry (Chen et al., 2003; Samaržija et al., 2012). Numeorus studies reported that psychrotrophic bacteria were the most common causes of post-pasteurization contamination of dairy products (Eneroth et al., 1998; Larsen and Jørgensen, 1999; Fromm and Boor, 2004; Santana et al., 2004; Hickey et al., 2015). Besides, almost all species adhere to solid surfaces and form hardly removable biofilms (Watnick and Kolter, 2002; Mostert and Buys, 2008; Raajimakers et al., 2010). Milk can become contaminated by a large variety of spoilage microorganisms from many contamination sources (environment, cow's udder, equipment), however the extent will be as great as the number of initially present above mentioned microorganisms in milk before further processing or packing.

Quality deterioration of cheese, in a form of cracks or texture failures, can result from the excess gas production by gas producing Streptococcus thermophilus or Lactobacillus helveticus, as well as by spore forming strains of Eubacterium sp., Clostridium tyrobutyricum and related species. Due to low $\mathrm{pH}$ values and rich nutritional profile, cheeses are favourable for spoilage by yeasts that rapidly grow especially on the surface (Ledenbach and Marshall, 2009). Thus, vacuum or modified atmosphere packed cheeses can erupt due to large quantities of $\mathrm{CO} 2$ due to product storage and maturation. Cream cheeses are also liable to spoilage induced by heat resistant molds like Byssochlamys nivea which can grow in atmospheres containing even less than $0.5 \%$ oxygen.

Not only microbial factors are responsible for spoilage of milk and dairy products. The present microflora often produces thermo-resistant enzymes with lipolytic and proteolytic activities resulting in changes on lipids and proteins. Those changes will reflect on quality of not only milk, but also in fermented products and cheeses. They can be recognised as untypical yoghurt-like flavour, bitter off-flavour, rancidity, undesired textural changes, increased free fatty acid contents etc. (Braun et al., 1999; Ledenbach and Marshall, 2009, Samaržija et al., 2012). The increase in free fatty acid content often results in lipid oxidation which in turn leads to oxidative rancidity. This is one of the major causes of deterioration in milk and dairy products. Lypolisis of milk occurs at larger extent in the presence of high oxygen levels, in the absence of ascorbic acid and during the exposure to light. Among numerous important factors reducing or retarding oxidation, often commercialised tool is application of appropriate packaging material and inert gas and/or vacuum packing (Fox et al., 2015).

Thus, the properties of milk and dairy products make packaging to be considered as a critical step regarding the applied technological operations. If the choice of packaging is inappropriate or there is failure during handling, transportation, and storage of dairy products, all benefits of the applied processing steps would become useless (Alvarez and Pascall, 2011).

\section{Packaging of milk}

Contemporary milk packaging materials include metals, glass, plastics, and composite materials.

Traditionally the glass bottle has held the field through changing times for over than 60 years considering liquid milk packaging. It started with quite heavy and clumsy bottles capped with cardboard. Glass bottles with narrow $(\mathrm{d}=26 \mathrm{~mm})$ or wide $(\mathrm{d}=35-40 \mathrm{~mm})$ necks were proved to be the most appropriate for milk packaging (Karaman et al., 2015). As usual glass has several disadvantages, such as high production costs, brittleness, heaviness etc. Over the years the bottle has been continually improved resulting in lesser weighs, tougher and cheaper material. Glass is the most inert of all food packaging materials and provides protection from oxygen, moisture, and microorganisms. When colored appropriately (blue, amber, green, white), glass can protect milk from harmful UV light (Kontaminas 2019).

Despite that, traditional glass bottles are nowadays rarely used for milk storage and distribution. More comon materials include plastic and multilayer packaging materials, metal (aluminium and tinplate) cans. Aluminium cans are often used to pack vitamin-fortified milk or flavoured beverages (such as milk like coffee, vanilla, chocolate etc.). The interior of aluminum cans is lacquered to protect its content against corrosion (Kontaminas 2010).

Main advantages of aluminium cans is their durability, lightweight and recyclability (Alvarez and Pascall, 2011). However, there are several disadvantages like high production costs and potentially high risk of product contamination by heavy metalas especially when unlacqured cans are used (Adams and Happiness, 2010). Those hazards may enter the milk chain during primary production. High contamination levels by the end of milk processing can also result as leaching from the lacquer used for metal can or the plastic lining of cans or surfactants due to contact with can coating during processing and storage (Adams and Happiness, 2010; Karaman et al., 2015).Aluminium finds its application also in the form of foil used for sealing of milk bottles (Deshwal and Panjagari, 2020).

Condensed milk and evaporated milk are packaged into rigid containers such as tinplate cans (Ramonaityte 2001; Adams and Happiness 2010). Some milk products are packed in plain tinplate of coating weight $8.4 \mathrm{~g}$ / $\mathrm{m} 2$, while some lacquered cans are used with coating weight of $5.6 \mathrm{~g} /$ $\mathrm{m} 2$. Evaporated and condensed milk packed in metal cans with lacquer coatings remains shelf-stable for 6 months to 1 year (Deshwal and Panjagari, 2020).

The main plastic materials used for packaging of various types of liquid milk are high density polyethylene (HDPE), polyethylene terephthalate (PET), polycarbonate (PC) and low density polyethylene (LDPE) (Kontominas, 2010). In comparison to glass or metal, well designed barrier plastics have numerous advantages because they can be also durable, good moisture and oxygen barriers, flexible, lightweight and cheaper to produce. In some countries like the UK, Canada or USA, HDPE bottles are very popular for pasteurized milk packaging. Besides, being easy to mechanically be modeled with higher softening temperature $\left(121^{\circ} \mathrm{C}\right)$, HDPE can therefore be heat sterilized and resistant to solvents. On the other hand, it offers low protection against light. HDPE can also be extruded into films, aimed for use as pouches. Co-extruded HDPE bottles have been used in the past decade for packing of UHT sterilised milk (Alvaraez and Pascall, 2011; Karaman et al, 2015). Next to HDPE, PET is another plastic material that is often used for packaging of liquid milk products like whole, skimmed, ultra-pasteurised, UHT sterilised, flavoured, cultured or micro-filtered milk (Kontominas, 2010). In comparison to HDPE, PET is characterised by much better mechanical and gas barrier properties. Besides, PET shows less adverse effects on milk flavour than HDPE (Kontominas, 2010, Karaman et al., 2015). Since they are almost completely transparent, PET bottles are often pigmented or covered by thermo-shrinkable polypropylene (PP) film in order to ensure protection against light-induced changes. For example, milk packed into clear PET bottles and exposed to light had significantly 
lower contents of vitamins A (48 IU*/100 ml) and B2 $(0 \mu \mathrm{g} / 100 \mathrm{ml})$ in comparison to samples packed into pigmented PET bottles (211 IU*/100 $\mathrm{ml}$ and $76 \mu \mathrm{g} / 100 \mathrm{ml}$ of vitamin A and B2, respectively) stored for 12 weeks (Saffert et al., 2009).

Liquid milk can be also packed into LDPE or linear LDPE (LLDPE) pouches due to their high melting strength, high resistance to tearing and pinholes and excellent seal integrity. Pinto et al. (2014) investigated the LDPE pouches for packing extended shelf life (ESL) milk processed by the combined process of pasteurization and microfiltration. According to the obtained results, all of the tested pouches were suitable for ESL milk packaging. However, principal disadvantage is that once opened, pouches cannot be reclosed. This leads to the exposure of milk to the external environement and to the absorption of contaminant odours (Kontominas, 2010). Some of advances in such flexible packaging was introduced by a Swedish producer Ecolean who developed a combined packaging film made of $40 \%$ calcium carbonate (chalk) blended with conventional PP and PE. Chalk addition provides better stiffness and whiteness, reduces weight of the package, reduces cost and presents a good gas and light barrier. Thus, possibility of oxidative degradation is reduced to a minimum. Such pouches enable the extension of milk shelf life up to six-month even if kept at ambient conditions (Anonymus). These pouches could also be commercially used for UHT milk packaging and might provide even a yearlong shelf life (Reynolds, 2012).

Very popular and convenient type of liquid milk packaging, especially UHT sterilised milk, are multilayer containers composed of printed paper coated with aluminium foil (Alu) and polyethylene (PE) layers. The aluminium foil acts as light and gas barrier, while the paper (PAP) gives the required mechanical strength. The inner material side of the finished package is coated with a special layer (PE) facilitating the sealing process and providing a liquid barrier (Patel et al., 2017). Popular solutions are presented under commercial names Tetra Pak ${ }^{\circledR}$, Tetra Brik ${ }^{\circledR}$ and PurePak ${ }^{\circledR}$ forms intended for aseptic filling of UHT long-life milk.

Novel packaging systems, which include active and smart packaging, have been also introduced in milk packaging. It was demonstrated that antimicrobial active packaging films (prepared by coating silver nanoparticles on LDPE) can be efficient against microorganisms present in milk thus increasing its shelf life (Bandpey et al., 2016).

With regards to food-package interaction it was observed that it is not only the fat content of the foodstuff, such as in dairy products, that influences the migration of lipophilic migrants from the packaging to the food item. Factors, such as the ratio of fat/water content and the consistency of the foodstuff may also play an important role in the migration process (Cruz et al., 2008).

Compounds such as Bisphenol A (BPA, 2,2-bis(4-hydroxyphenyl) residues may be found in the milk as result of migration from plastic parts (plastic resins, PVC tubing, polycarbonate production) during milking, from milking machines or during transfer from bulk milk to storage tanks of bigger volumes or to smaller containers for distribution and selling (Santonicola et al., 2019).

\section{Packaging of fermented milk products}

Despite the low $\mathrm{pH}$, fermented milks such as yogurt, kefir, sour milk or acidified buttermilk are also perishable products and require proper packaging to prevent undesirable changes in psychochemical, nutritional and sensory characteristics. There is an increasing interest in packaging features comes due to yoghurt's significant market production and demand. Even though there is notable development of various nutraceutical food, fermented milk still remains the most popular probiotic food carrier (Khorshidian et al., 2020). The major factors for determining the shelf life and quality of yoghurt products are proliferation of yeasts and moulds, development of off-flavours as well as survival and the availability of probiotic bacteria (Robinson et al. 2002; Viljoen et al. 2003). Besides, due to the ability to interact with hydrophobic and hydrophilic materials, fermented milks may adhere to packaging materials forming an inner film. According to some calculations, approximately $10 \%$ of all fermented milks remain on the inside of packaging material (Hansson et al., 2012). Packaging for yoghurt is classified into three main categories regarding the physical strength of the container -semi-rigid, flexible and rigid containers. Semi-rigid containers are usually produced from plastics such as PE, $\mathrm{PP}$, polystyrene (PS), poly(vinyl-chloride) (PVC) and poly(vinylidene chloride) (PVDC) laminates (PVC/PVDC). Those are convenient due to relatively low water vapour, oxygen, and nitrogen transmission rates, as well as for being acid resistant and preventing the loss of volatile flavours (Alvarez and Pascall, 2011). Semi-rigid containers are usually in form of cups and tubs with rigid bodies and flexible lids (Karaman et al., 2015). Another semi-rigid forms are carton based laminates (PE/Alu/PE or PE/ $\mathrm{PAP} / \mathrm{Alu} / \mathrm{PE}$ ) used for dehydrated yogurt (Alvarez and Pascall, 2011). Currently one of the most popular materials used for spoonable yogurt packaging is thermoformed high impact polystyrene (HIPS) shaped into small cups or larger tubs, with either an aluminium foil/plastic laminate or a paper/plastic laminate heat-seal lid or closure. In order to improve the appearance and to provide certain protection from light induced changes, commonly TiO2 is added (Galić, 2016; Robertson, 2016). For spoonable fermented milk products with extended shelf life reaching even 4-6 months at ambient temperatures, laminated materials are desirable. A good $\mathrm{O} 2$ barrier packaging will prevent the oxidation, and a good light barrier will help to delay fading of light-sensitive colours and light-induced oxidation (Galić, 2016). Flexible containers mainly include plastic pouches. More recently, popular are becoming the standup pouches with a screw-type caps (Karaman et al., 2015).

Considering fermented milks, special focus needs to be put on products containing probiotic cultures. Mattila-Sandholm et al. (2002) concluded that the choice of packaging material and method is of crucial importance for insurance of desired quality of probiotic fermented milks throughout the determined shelf life. Since most of the commercially used probiotic strains are anaerobic or micro-aerophilic, they require low concentrations or complete absence of oxygen. Accordingly, the proper packaging material needs to be a good gas barrier like glass, which is still considered as a superior material in comparison to plastics that do not completely prevent gas permeation from the environment into the product. Due to high handling costs of glass, plastics are the second best solution and are commonly used for fermented milk packaging. Along with technological progress, intelligent and active packaging consisting of plastic laminates with incorporated oxygen absorbers (scavengers) are taking over the leadership among solutions for probiotic fermented milk packaging (Cruz et al., 2007.; Alvarez and Pascall, 2011; Karaman et al., 2015). Results of several studies confirmed that the use of multilayered materials like NupakTM containers (combination of HIPS, ethylene vinyl alcohol (EVOH) and PE, (Visypac, Melbourne, Australia)), especially when containing oxygen absorbers provide the best protection for probiotic foods (Miller et al., 2003a, 2003b; Talwalker et al., 2004; Kudleka, 2005). Extrinsic factors, i.e. storage time and temperature will influence the survival of probiotic species and knowledge of their variatioons is therefore of a great importance. Generally, storage at higher temperatures will significantly decrease the viability of microorganisms while storage at lower temperatures, at -20 to $4{ }^{\circ} \mathrm{C}$ are known to be better conditions for the survival of probiotic strains cultivated in yoghurt (Cabello-Olmo et al., 2020).

Various preservation technologies have been developed to extend shelf life of these products by taking into account the effect on spoilage and the growth of desirable micro-organisms. Thus, in order to ensure the viability of probiotic bacteria several methods might be combined like the use of multilyered plastic material with incorporated oxygen absorbent, microencapsulation of probiotic strains, addition of carbon dioxide and storage at low temperatures (Lopez-Rubio et al., 2004; Rathore et al., 2013; Dobrucka and Cierpiszewski, 2014; Tripathi et al., 2014, Ramos et al., 2015). Among mentioned, innovative technologies such as the use of microencapsulated probiotics, ultrasonication, the inclusion of prebiotics, use of appropriate packaging and optimal storage conditions 
have been also reported, contributing to the promising stability and viability of probiotics included in fermented milk (Abesinghe et al., 2020).

\section{Butter packaging}

Due to a high fat content (82-88 \%) and the presence of moisture (up to $16 \%$ ), butter is extremely susceptible to light induced changes and oxidative deterioration. More precisely, the present free fatty acids, fat-soluble amino acids and carotene promote autoxidation under the influence of light, while microbial spoilage might also occur resulting in formation of putrid off-flavours. Accordingly, the packaging materials for butter have to provide proper protection from light influence, moisture and oxygen permeation into the product; should not contain metals since those favour fat oxidation and must be grease-proof (Patel et al., 2017). Butter is commonly wrapped into wet waxed, dry waxed, grease-proof, or vegetable parchment paper, or aluminium foil laminated with vegetable parchment or grease-proof paper. It was found that butter packaged into parchament paper solely develops oxidized off-flavours within few hours of exposure in a retail showcase. On contrary, if Alu laminates are used, there are no objectionable changes detected even after $48 \mathrm{~h}$ of continuous light exposure (Robertson, 2016). Consequently, Alubased laminates are used for butter packaging on a regular basis. Along with the development of dairy butter-containing spreads new packaging solutions consisting of thermoformed PP or LDPE containers with lids were introduced. Larger quantities of butter are commonly packed in 25 $\mathrm{kg}$ LDPE-lined paperboard cartons but also in cans if they are intended for longer period of storage (Alvarez and Pascall, 2011). Among other, recent studies also focus on the use of novel non-wooden biosources for production of paper as a raw material. For example, Sakare et al. (2020), successfully produced the banana pseudostem fiber based paper coated with carboxymethyl cellulose for butter packaging. Asdagh and Pirsa (2020) packed butter in active/smart film made from pectin/nanoclay (montmorillonite)/Carum copticum essential oils/ $\beta$-carotene during 90 das at $-4{ }^{\circ} \mathrm{C}$. Active films were shown to be a promising tool for improving the oxidative, microbial and colour stability, while presence of $\beta$-carotene led to colour changes of packaging material itself signalling the oxidation of butter and expiration time of butter (smart function).

\section{Cheese packaging}

Cheese is one of the most complex dairy products since it undergoes numerous biochemical processes resulting from microbial activity during the storage period. Among various types of cheese classification, in terms of packaging the most appropriate would be the one related to the moisture content and hardness. Accordingly, there are four main types of cheese - fresh, soft, semi-hard, hard and very hard cheeses. For cheeses that undergo the ripening process, besides the protective role, packaging material plays also a functional role since it regulates the permeation of vapour and gasses (Robertson, 2016). In that manner, the quality and abatement of packaged cheese are largely dependent on the permeability provided by the packaging material. When selecting the type of package, factors such as type of cheese, the presence of a specific microorganisms, type of sale (wholesale or retail), permeability to water vapour, oxygen, $\mathrm{CO} 2, \mathrm{NH} 3$ and light as well as labelling properties need to be considered (Alvarez and Pascall, 2011; Robertson, 2016). Due to high moisture and/or fat content, low salt concentration, and high $\mathrm{pH}$, fresh and cream cheeses are susceptible to microbial spoilage and photooxidation. Consequently, they require a packaging material that protects against light, oxygen transmission and moisture losses (Poças and Pintado, 2010; da Silva Ramos et al., 2015). Standard packages for these cheese types are HDPE, PP and thermoformed PS cups which provide a good moisture barrier. Additionally, those can be coated with PVDC to tighten the barrier and pigmented by $\mathrm{TiO} 2$ to assure the light protection (Alvarez and Pascall, 2011; da Silva Ramos et al., 2015). Soft cheeses are a very heterogeneous group of differently ripened cheeses with relatively high moisture content. The required softness level and the respiration rate are critical factors influencing the choice of packaging material and method (Poças and Pintado, 2010). Consequently, packaging materials with low water vapour permeability are considered appropriate since they allow the maintenance of the desired water activity level in cheese for purposes of proper cheese ripening by the added starter cultures. Thus, Alu, PP films or other convenient thermoformed packages based on PVC and PS are commonly used for blue veined cheeses like Roquefort, Stilton, Gorgonzola, etc. (da Silva Ramos et al., 2015). Additionally, for surface ripened cheese varieties like Camembert, Brie or Limburger it is important to consider the permeability of oxygen as well. In that manner, the most appropriate materials have proven to be perforated films of orientated polypropylene (OPP) or their combination with paper, lacquered cellophane and perforated lacquered aluminium foils (Poças and Pintado, 2010; da Silva Ramos et al., 2015). Semi-hard and hard cheeses are usually ripened under anaerobic conditions whereby packaging materials with low gas and vapour permeability are required. Historically, wax-based coatings containing refined paraffin or mineral oils have been used, but nowadays coextruded materials like polyamide (PA), PE, PET, PVDC or their combinations are commonly applied. For rindless cheeses packaging materials are often produced as laminates of polyethylene terephthalate - low density polyethylene (PET-LDPE) (300/50 $\mu \mathrm{m}$ thickness), cover film of oriented (O)PET-LDPE (23/75 $\mu \mathrm{m}$ thickness), tubular bags of oriented polyamide (OPA)-LDPE $(15 / 40 \mu \mathrm{m}$ thickness) and trough film of PET-HMLDPE (high molecular weight LDPE) $(200 / 25 / 25 \mu \mathrm{m}$ thickness). They are generally packed either in vacuum or under MAP conditions (Deshwal and Panjagari, 2020). One of the major problems associated to packaged cheeses is the development of moulds once the package has been opened. The invention of ziplock press-to-close resealable technologies that include an interlocking zipper on plastic pouches for cheese has solved this problem. Resealable packages can also involve a slider that features an ergonomically designed "clip" to enable an easy open and reclose a package. Both technologies are ideal for premade pouches and can run on all packaging formats and machinery configurations (Robertson, 2013)

In order to provide proper protection but also to achieve maximum quality and extend shelf-life, novel packaging methods such as active packaging (antimicrobial agents, oxygen absorbers, moisture absorpbers, UV-light apsorbers), intelligent packaging and edible coatings are increasingly being considered for use in dairy products packaging as well (Aliyu et al., 2018; Balbinot-Alfaro et al., 2019; Drago et al., 2020). Some of the latest studies are given below. Asmaa et al. (2021) used cellulose sheets fortified with Natamycin-loaded alginate nanoparticles, as a source of antimicrobial agents in Egyptian Romy cheese wrapping after 12 weeks of maturation. Authors showed that produced material could be an effective way of controlling toxigenic Aspergillus flavus and subsequent aflatoxin production without influencing the typical taste, color, flavor, and overall appearance of traditional Egyptian hard cheese (Asmaa et. al. 2021.). Humidipak ${ }^{\circledR}$, moisture controlling sachets with sodium propionate can be successfully used to control mold growth and to extended the shelf life significantly by decreasing the water loss of firm cheese (Pantaleão et al., 2007). New smart and active nanoparticles with a thermal sensing core and antibacterial, antioxidant, and UV-absorbing shell incorporated in food coating were efficient for the prolongation and improvement of shelf life of Ricotta cheese (Kritschenkov et al., 2021). Recently, an interesting survey of 403 scientific papers and 2272 patents about sustainable cheese packaging was published analysing relevant topics on biodegradable packaging and increasing cheese shelf life through active packaging while using both bioplastic with vegetal origin or synthetic plastics (Spreafico and Russo, 2021). Different active packaging systems applicable to cheese and brief studies on active packaging materials for cheese and its products are also presented in Table 1. 
Table 1. Different active packaging systems applicable to cheese (Deshwal and Panjagari, 2020)

\begin{tabular}{|c|c|c|c|}
\hline Type of active packaging & Variety of cheese & Description & References \\
\hline \multirow[t]{7}{*}{ Antimicrobial packaging } & Cottage cheese & $\begin{array}{l}\text { Sachets of allyl isothiocyanate were effective against yeast } \\
\text { and mold }\end{array}$ & $\begin{array}{l}\text { Conceicao Gon- } \\
\text { calves and Dos } \\
\text { Santos Pires, } 2009 .\end{array}$ \\
\hline & Mozzarella cheese & $\begin{array}{l}\text { Lysozyme and ethylenediaminetetraacetic disodium salt } \\
\text { (Na2-EDTA) inhibited the growth of coliform and Pseu- } \\
\text { domonadaceae without affecting the lactic acid bacteria }\end{array}$ & $\begin{array}{l}\text { Sinigaglia et al., } \\
2008 .\end{array}$ \\
\hline & Kashar Cheese & $\begin{array}{l}\text { Zein and zein-wax coating with lysozyme, catechin and gallic } \\
\text { acid. Lysozyme based film prevented the growth of Listeria } \\
\text { monocytogens }\end{array}$ & Unalan et al., 2013. \\
\hline & Mozzarella cheese & $\begin{array}{l}\text { Packages containing calcium lactate and lactic acid-based } \\
\text { brine enhanced the shelf-life by } 50 \%\end{array}$ & Faccia et al., 2019. \\
\hline & Surface ripened cheese & $\begin{array}{l}\text { Polyethylene films coated with polyvinyldichloride and } \\
\text { containing natamycin/nisin possessed inhibitory effect } \\
\text { against Penicillium expansum in surface ripened cheese } \\
\text { i.e. Blatacke zlato and Olomoucke tvaruzky }\end{array}$ & $\begin{array}{l}\text { Huvaere and Skibst- } \\
\text { ed, } 2015 \text {. }\end{array}$ \\
\hline & Zamorano sheep cheese & $\begin{array}{l}\text { Poly propylene and polyethylene terephthalate films } \\
\text { with Origanum vulgare and ethyl lauroyl arginate essential } \\
\text { oils inhibited E.coli O157:H7 }\end{array}$ & Otero et al., 2014. \\
\hline & Saloio cheese & $\begin{array}{l}\text { Whey protein isolate coating containing natamycin reduced } \\
\text { water loss, color changes and microbial growth throughout } \\
\text { the storage period of } 60 \text { days }\end{array}$ & Ramos et al., 2012. \\
\hline \multirow[t]{4}{*}{ Oxygen absorbers } & $\begin{array}{l}\text { Low fat cheese }(5 \% \text { fat } \\
\text { in dry matter })\end{array}$ & $\begin{array}{l}\text { Microbial oxygen absorber; Contains microorganisms which } \\
\text { utilizes oxygen e.g. Lactococcus lactis strain; Flavor and } \\
\text { odor improved }\end{array}$ & $\begin{array}{l}\text { Lillevang et al., } \\
2014 .\end{array}$ \\
\hline & $\begin{array}{l}\text { High fat cheese }(60 \% \text { fat } \\
\text { in dry matter })\end{array}$ & $\begin{array}{l}\text { Microbial oxygen absorber containing Lactococcus lac- } \\
\text { tis strain; Flavor improved and no explicit difference on odor }\end{array}$ & $\begin{array}{l}\text { Lillevang et al., } \\
2014 .\end{array}$ \\
\hline & Cheddar cheese & $\begin{array}{l}\text { Microbial oxygen absorber containing Lactococcus lac- } \\
\text { tis strain; Positive influence on shelf-life }\end{array}$ & $\begin{array}{l}\text { Lillevang et al., } \\
2007 .\end{array}$ \\
\hline & Delite $5 \%$ sliced cheese & $\begin{array}{l}\text { Microbial oxygen absorber containing Lactococcus lac- } \\
\text { tis strain; Positive influence on product characteristics }\end{array}$ & $\begin{array}{l}\text { Lillevang et al., } \\
2007 .\end{array}$ \\
\hline \multirow[t]{2}{*}{ Moisture absorbers } & Saloio cheese & $\begin{array}{l}\text { Humidipak } \AA \text {, Moisture controlling sachets with sodium } \\
\text { propionate impregnated over it to control mold growth. Ex- } \\
\text { tended the shelf-life significantly by decreasing the water loss }\end{array}$ & $\begin{array}{l}\text { Pantaleao, Pintado } \\
\text { and Pocas, } 2007 .\end{array}$ \\
\hline & Camembert cheese & $\begin{array}{l}\text { 3-layered film with absorber/desorber film. } 10 \% \text { concentra- } \\
\text { tion of water absorbent, maintained attractive white appear- } \\
\text { ance of cheese while } 25 \% \text { caused damage of the varnish layer } \\
\text { due to swelling. }\end{array}$ & $\begin{array}{l}\text { Desobry and Hardy, } \\
1994 .\end{array}$ \\
\hline UV light absorbers & Cheese puffs & $\begin{array}{l}\text { Tricalcium phosphate-based UV light inhibitor could be } \\
\text { incorporated directly into dry mix flavor powder of cheese } \\
\text { puffs cooked in hot oil to prevent light induced rancidity and } \\
\text { spoilage. }\end{array}$ & $\begin{array}{l}\text { Swartz and Hartford, } \\
1999 .\end{array}$ \\
\hline
\end{tabular}

\section{Dehidrated dairy products}

Dehydration belongs to one of the oldest technologies used to extend the shelf life of milk and dairy products. This operation inhibits the growth of bacteria, yeast and moulds through the removal of water, and stabilizes milk constituents for their storage and later use. Dry milk products currently include milk powder, skim milk powder, whey powder, various whey

protein powders, dry dairy-based beverages, casein, caseinates, coprecipitates, infant formula and cheese products, lactose, coffee whiteners, and dry ice cream mixes (Schuck, 2011). For many years milk concentration by evaporation and subsequent vacuum drying on drum rollers have been the only option for producing milk powder and similar products. However modern technologies such as reverse osmosis filtration, spray drying, fluid bed drying, superheated steam drying or microwave vacuum dehydration technologies allow the manufacture of milk powders with high nutritional value. When choosing packaging of milk powders, it is important to protect the powder from moisture, air, light, insects, and other external influencers. Among all factors that need to be considered, moisture is the most important one, particularly the water activity (aw) and the glass transition temperature $(\mathrm{Tg})$, since these powders are characterised by high levels of hygroscopicity.

Since these products are usually intended to be stored for a longer period, packing is carried out in an atmosphere of inert gas, or under a partial vacuum of 4.0-5.3 kPa, in order to achieve very low oxygen concentration (less than $4 \%$ ) and avoid oxidative changes in fat and other milk components (Schuck, 2011; Deshwal and Panjagari, 2020). These conditions are especially important for fat containing dairy products like whole milk powder, butter milk powder or cream powder. Skim milk powder has a low fat content (approximately 1\%) and does not need to be vacuum packed or flushed 


\section{Table 2. Shelf-life of packaged dairy products}

\begin{tabular}{|c|c|c|c|c|}
\hline Dairy product & Packaging material characteristics* & Packaging method & Storage conditions or shelf-life & Refere-nces \\
\hline Pasteurized (HTST) milk & $\mathrm{PE} / \mathrm{PAP} / \mathrm{PE}$ & Aseptic & $14-17$ days at $6^{\circ} \mathrm{C}$ & $\begin{array}{l}\text { Fromm and } \\
\text { Boor, } 2004 .\end{array}$ \\
\hline \multirow[t]{2}{*}{ Pasteurized (HTST) milk } & Bottle: PE-HD+TiO2 & & $\begin{array}{l}2^{\circ}(43 \mathrm{~d}), 4^{\circ}(36 \mathrm{~d}), 9^{\circ}(8 \mathrm{~d}), 14^{\circ} \\
(5 \mathrm{~d}), \text { and } 16{ }^{\circ} \mathrm{C}(3 \mathrm{~d})\end{array}$ & $\begin{array}{l}\text { Petrus, } \\
\text { Loiola and } \\
\text { Oliveira, } \\
2010 .\end{array}$ \\
\hline & Pouch: PE-LD+TiO2 & & $\begin{array}{l}2^{\circ}(37 \mathrm{~d}), 4^{\circ}(35 \mathrm{~d}), 9^{\circ}(7 \mathrm{~d}), 14^{\circ} \\
(3 \mathrm{~d}) \text {, and } 16^{\circ} \mathrm{C}(2 \mathrm{~d}) .\end{array}$ & \\
\hline \multirow[t]{3}{*}{ Flavoured stirred yogurts } & Glass bottle (control) + lid: $\mathrm{Al}+\mathrm{PE}$ & & 28 days at $4{ }^{\circ} \mathrm{C}$. & $\begin{array}{l}\text { Sanint-Eve } \\
\text { et al., } 2008 \text {. }\end{array}$ \\
\hline & $\begin{array}{l}\text { PS-HI +crystal PS= 50/50 ratio. } \\
\text { Lid: PE/PP }\end{array}$ & & & \\
\hline & $\mathrm{PP}+$ lid: $\mathrm{Al}+\mathrm{PE}$ & & & \\
\hline \multirow[t]{5}{*}{$\begin{array}{l}\text { Provolone (semi-hard } \\
\text { drawn-curd) cheese }\end{array}$} & $\begin{array}{l}\mathrm{PA} / \mathrm{PE}(20 / 80 \mathrm{~mm}): \mathrm{P}(\mathrm{O} 2)=50 \mathrm{~cm} 3 / \\
\mathrm{m} 224 \mathrm{~h} \text { bar }\left(\text { at } 23{ }^{\circ} \mathrm{C}\right)\end{array}$ & $\mathrm{CO} 2 / \mathrm{N} 2: 10 / 90$ & 100 days at $8^{\circ} \mathrm{C}$ & $\begin{array}{l}\text { Favati, } \\
\text { Galgano and } \\
\text { Pace, } 2007 .\end{array}$ \\
\hline & & $\mathrm{CO} 2 / \mathrm{N} 2: 20 / 80$ & 118 days at $8^{\circ} \mathrm{C}$ & \\
\hline & & $\mathrm{CO} 2 / \mathrm{N} 2: 30 / 70$ & 280 days at $8^{\circ} \mathrm{C}$ & \\
\hline & & $\mathrm{CO} 2 / \mathrm{N} 2: 100 / 0$ & 175 days at $8^{\circ} \mathrm{C}$ & \\
\hline & & vacuum (control) & 190 days at $8^{\circ} \mathrm{C}$ & \\
\hline \multirow[t]{4}{*}{$\begin{array}{l}\text { Fresh } \\
\text { (acid coagulated) cheese }\end{array}$} & $\begin{array}{l}\mathrm{PA} / \mathrm{PE}(90 \mathrm{~mm}): \mathrm{P}(\mathrm{O} 2)=22.3 \mathrm{~cm} 3 / \\
\mathrm{m} 224 \mathrm{~h} \mathrm{bar}\left(\text { at } 23{ }^{\circ} \mathrm{C}\right) \text { and } 3.7 \mathrm{~cm} 3 / \\
\mathrm{m} 224 \mathrm{~h} \text { bar }\left(\text { at } 4{ }^{\circ} \mathrm{C}\right)\end{array}$ & $\mathrm{CO} 2 / \mathrm{N} 2: 40 / 60$ & 18 days at $4{ }^{\circ} \mathrm{C}$ & $\begin{array}{l}\text { Barukčić et } \\
\text { al., } 2020 .\end{array}$ \\
\hline & & $\mathrm{CO} 2 / \mathrm{N} 2: 30 / 70$ & 18 days at $4^{\circ} \mathrm{C}$ & \\
\hline & & vacuum & 18 days at $4{ }^{\circ} \mathrm{C}$ & \\
\hline & & $\begin{array}{l}\text { atmosphere (air) } \\
\text { (control) }\end{array}$ & 9 days at $4{ }^{\circ} \mathrm{C}$ & \\
\hline
\end{tabular}

polystyrene; $\mathrm{PP}=$ polypropylene; $\mathrm{PS}=$ polystyrene; $\mathrm{PA}=$ polyamide $($ nylon $) ; \mathrm{P}(\mathrm{O} 2)=$ oxygen permeability; $\mathrm{d}=$ day

with an inert gas.

Thus the most effective method of extending the shelf life of milk powder is to package it in a high oxygen barrier materials (Robertson 2016), why most common packaging material for milk powder is a combination of multilayer $50 \mathrm{~kg}$ kraft paper and one layer of polyethylene lining (25-75 mm thickness) (Schuck, 2011).

Metal barrels lined with polyethylene bags, or cans sealed with aluminum foil, are also used for packing such powdered products (Schuck, 2011), although nowadays tinplate cans have been replaced with Alu/plastic laminates. The main advantages of using laminates are lower material cost and lighter material weight. The disadvantages are that they do not have the mechanical strength and durability as metal containers. Furthermore, it could be difficult to obtain a satisfactory heat seal because of seal area contamination by powder during filling.

A typical design of such laminate is made of an inner layer of LDPE (sealing function) and an outer layer of biaxially oriented polypropylene (BOPP) or PET with Alu in the middle. For the products for which a shorter shelf life is acceptable, the Alu layer may be replaced with a highbarrier plastic layer such as EVOH or PVDC copolymer, and the PET may be coated with inorganic layer (such as SiOx) (Robertson 2016). All milk powders can be stored at ambient temperature for a limited time, if properly produced and packed.

It was investigated that the shelf life of the vacuum dried coconut milk powder, in Alu/PE laminate, was 30 days, at $90 \% \mathrm{RH}$ and $38^{\circ} \mathrm{C}$, where moisture gain was found to be the critical parameter for its stability (Jena and Das, 2012).

Smart packaging was also demonstrated on oxygen-sensitive dairy products (such as milk powder). The study of Kulchan et al., (2016) showed that a novel colorimetric indicator could be accurately used for monitoring rancidity reaction of milk powder. Thus, a shelf life study of this product was estimated to be 26 days.

Shelf-life of some packaged dairy products are presented in Table 2.

\section{Ice cream packaging}

Ice cream belongs to the most complex dairy products since it comprises a frozen matrix consisting of milk, cream and various additives like sweeteners, stabilizers, emulsifiers, flavourings, colouring agents, eggs, starch hydrolysates, whey protein concentrates, etc.

The technology of ice cream production is also very specific and includes the pasteurization, homogenization and aging of ice mixture, followed by rapid freezing with vigorous agitating to incorporate air for achieving a smooth and soft final product. Taking all of that into consideration, the most important requirements for the ice cream packaging are to provide protection against contamination, moisture loss and preferably temperature fluctuations, as well as to appear attractive to consumers and to be easy for opening. In the case of bulk ice cream packaging, it is also important to enable a proper hardening which is occurring after the packaging step. Accordingly, for an ice cream, packaging commonly comprises various polystyrene or high impact polystyrene containers (disposable cups, plates, cassette boxes). More recently, some bio-based packaging materials like acetylated monoglicerids have been proposed since they have a good moisture barrier properties (Patel, Modha and Randganadham, 2017). 


\section{Conclusions}

In recent years, there was a tremendous increase in the use of plastic that replaces the traditional packaging materials such as glass, metal and paper. Packaging generally can also protect products against moisture loss or gain, dust, and light, especially UV light, which causes deterioration of some light-sensitive products. It can also protect the package contents against temperature fluctuations in the transit of chilled and frozen foods. Proper milk and dairy products packaging may also protect the product against microbial spoilage by bacteria, yeasts, and molds. The shelf life of a milk and milk products depend upon the product and the packaging system used, the specifications of packaging material and the storage conditions in which it is held.

\section{References}

Abesinghe A.M.N.L., Priyashantha H., Prasanna P.H.P., Kurukulasuriya M.S., Ranadheera C.S., Vidanarachchi J.K. (2020) Inclusion of Probiotics into Fermented Buffalo (Bubalus bubalis) Milk: An Overview of Challenges and Opportunities. Fermentation, 6 121. https://doi.org/10.3390/ fermentation6040121

Adams I.U., Happiness I.U. (2010) Estimation of toxic metals in canned milk products from unlaquered tin plate cans. Journal of American Science, $6(5) 173-178$.

Aliyu M., Hajian R., Yusof N.A., Shams N., Jaafar A., Woid, P.M.W., Garmestani H. A. (2018) Screen printed carbon electrode modified with carbon nanotubes and gold nanoparticles as a sensitive electrochemical sensor for determination of thiamphenicol residue in milk. RSC Advances, 8 2714-2722.

Alizadeh A.M., Masoomian M., Shakooie M., Zabihzadeh Khajavi M., Farhoodi M. (2020) Trends and applications of intelligent packaging in dairy products: a review. Critical Reviews in Food Science and Nutrition, https://doi.org/10.1080/10408398.2020.1817847

Alvarez V., Pascall M. (2011) Packaging In: Encyclopedia of Dairy Sciences, 2nd ed.; (Fuquay, J., Fox, P., McSweeney, P., Eds.), Academic Press, San Diego, CA, USA, pp 16-23.

Anonymus : http://blog.drupa.com/de/ecolean-packaging/ Accesed at 01.02.2021.

Balbinot-Alfaro E., Craveiro D. V., Lima K. O., Costa H. L. G., Lopes D. R., Prentice C. (2019) Intelligent Packaging with pH Indicator Potential. Food Engineering Reviews, 11 235-244. https://doi.org/10.1007/s12393-019-09198-9

Asdagh A., Pirsa S. (2020) Bacterial and oxidative control of local butter with smart/active film based on pectin/nanoclay/Carum copticum essential oils/ß-carotene. International Journal of Biological Macromolecules, 165 156-168. https://doi.org/10.1016/j.ijbiomac.2020.09.192

Asmaa F., Huda E., Taghreed A. (2021) Packaging fortified with Natamycin nanoparticles for hindering the growth of toxigenic Aspergillus flavus and aflatoxin production in Romy cheese. Journal of Advanced Veterinary and Animal Research, 8 (1) 58-63.

Bandpey N.B., Aroujalian A., Raisi A., Fazel S. (2016) Surface coating of silver nanoparticles on polyethylene for fabrication of antimicrobial milk packaging films. International Journal of Dairy Technology, 70 (2) 204-211. https://doi.org/10.1111/1471-0307.12320

Barukčić I., Ščetar M., Marasović I., Lisak Jakopović K., Galić K., Božanić R. (2020) Evaluation of quality parameters and shelf life of fresh cheese packed under modified atmosphere. Journal of Food Science and Technology, 57 (7) 2722-2731. https://doi.org/10.1007/s13197-020-04308-6

Braun P., Fehlhaber K., Klugand C., Kopp K. (1999) Investigations into the activity of enzymes produced by spoilage-causing bacteria: a possible basis for improved shelf-life estimation. Food Microbiology, 16 531-540.

Chen L., Daniel R.M., Coolbear T. (2003) Detection and impact of protease and lipase activities in milk and milk powder (review). International Dairy Journal, 13 255-275.

Conceicao Goncalves M.P.J, Dos Santos Pires A.C., Soares N.D.F.F., Araujo E.A. (2009) Use of allyl isothiocyanate sachet to preserve cottage cheese. Journal of Foodservice, 20 275-279.

Cruz A.G., Faria A.F.J., Van Dender A.F.G. (2007) Packaging system and probiotic dairy foods. Food Research International, 40 951-956.

Cruz J.M., Sanches Silva A., Sendón García R., Franz R., Paseiro Losada P. (2008) Studies of mass transport of model chemicals from packaging into and within cheeses. Journal of Food Engineering, 87 107-115.

Da Silva Ramos O.L., Perreira R.N.C., Martins J.T., Malcata F.X. (2015) Edible Packaging for Dairy Products In: Edible Food Packaging - Materials and Processing Technologies (Cerqueira, M.A.P., Pereira, R.N.C., da Silva Ramos, O.L., Teixeira, J.A.C., Vicente, A.A., eds), CRC Press, Talyor \& Francis, pp. 383-412.

Deshwal Kr.G., Panjagari N.R. (2021) Active and Intelligent Packaging of Cheese: Developments and Future Scope. https://doi.org/10.5772/ intechopen. 95502

Desobry S., Hardy J. (1994) Camembert cheese water loss through absorbent packaging. Journal of Food Science, 59 986-989.

Drago E., Campardelli R., Pettinato M., Perego P. (2020) Innovations in Smart Packaging Concepts for Food: An Extensive Review. Foods, 9 (11) 1628. doi:10.3390/foods9111628

Dobrucka R., Cierpiszewski R. (2014) Active and Intelligent Packaging Food - Research and Development - A Review. Polish Journal of Food and Nutrition Sciences, 64 (1) 7-15.

Eneroth A., Christiansson A., Brendehang J., Molin G. (1998) Critical Contamination Site in the Production Line of Pasteurised Milk, with Reference to the Psychrotophic Spoilage Flora. International Dairy Journal, 8 829-834.

Faccia M., Gambacorta G., Natrella G., Caponio F. (2019) Shelf life extension of Italian mozzarella by use of calcium lactate buffered brine. Food Control, 100 287-291.

Favati F., Galgano F., Pace A.M. (2007) Shelf-life evaluation of portioned Provolone cheese packaged in protective atmosphere, LWT, $40480-488$. Fox P.P., Uniacke-Lowe T., McSweeny P.N.H., O'Mahoney J.A. (2015) Dairy Chemistry and Biochemistry, 2nd Edition, Springer International Publishing Switzerland.

Fromm H.I., Boor K.J. (2004) Characterization of Pasteurized Fluid Milk Shelf-life Attributes. Journal of Food Science, 69 (8) $207-214$.

Galić K. (2016) Packaging materials and methods for dairy applications. New Food Magazine, Issue 4. Available at https://www.newfoodmagazine. com/article/26394/packaging-materials-dairy/.

Hansson K., Andersson T., Skepö M. (2012) Adhesion of fermented dairy products to packaging materials. Effect of material functionality, storage time, and fat content of the product. An empirical study. Journal of Food Engineering, 111 318-325. 
Hickey C.D., Sheehan J.J., Wilkinson M.G., Auty M.A.E. (2015) Growth and location of bacterial colonies within dairy foods using microscopy techniques: a review. Frontiers in Microbiology, 6 (99) 1-8.

Huvaere K., Skibsted L.H. (2015) Flavonoids protecting food and beverages against light. Journal of the Science of Food and Agriculture, 95 20-35. Jena S., Das H. (2012) Shelf life prediction of aluminum foil laminated polyethylene packed vacuum dried coconut milk powder. Journal of Food Engineering, 108 135-142.

Karaman A.D., Özer B., Pascall M.A., Alvarez V. (2015) Recent Advances in Dairy Packaging. Food reviews International, 31 295-318.

Kontominas M.G. (2010) Packaging and the Shelf Life of Milk. In: Food packaging and shelf life: a practical guide (Robertson, G.L., ed). Taylor and Francis Group, LLC, pp. 81-103.

Kulchan R., Boonsupthip W., Jinkarn T., Suppakul P. (2016) Developing a novel colorimetric indicator for monitoring rancidity reaction and estimating the accelerated shelf life of oxygen-sensitive dairy products. International Food Research Journal, 23(3) 1092-1099.

Larsen H.D., Jørgensen K. (1999) Growth of Bacillus cereus in pasteurized milk product. International Journal of Food Microbiology, 46 173-176.

Ledenbach L.H., Marshall R.T. (2009) Microbiological Spoilage of Dairy Products in Compendium of Microbiological Spoilage of Food and Beverages (Sperber, W.H.; Doyle, M.P., Eds), Springer, UK. pp. 41-67.

Lillevang S.K., Mortensen G., Kristensen M., Pedersen H.S., Friis T.L., Sorensen N.K. (2007) Microbial oxygen absorber. U.S. Patent Application No. 11/602,328. U.S. Patent and Trademark Office. Washington, DC.

Lillevang S.K., Mortensen G., Kristensen M., Pedersen H.S., Friis T.L., Sorensen N.K. (2014) Microbial oxygen absorber. U.S. Patent Application No. 14/307,979. U.S. Patent and Trademark Office. Washington, DC.

Lopez-Rubio A., Almenar E., Hernandez-Munoz P., Lagaron J.P., Catala R., Gavara R. (2004) Overview of Active Polymer-Based Packaging Technologies for Food Applications. Food Reviews International, 20 (4) 357-387.

Mattila-Sandholm T., Myllarinen P. M., Crittenden R., Mogensen G., Fonden R., Saarela M. (2002) Technological challenges for future probiotic foods. International Dairy Journal, 12 173-182.

Miller C., Nguyen M., Rooney M., Kailasapthy K. (2003a). The influence of packaging materials on the dissolved oxygen content of probiotic yogurt. Packaging Technology and Science, 15 133-138.

Miller C.W., Nguyen M.H., Rooney K., Kailasapathy K. (2003b) The control of dissolved oxygen content in probiotic yogurts by alternative packing materials. Packaging Technology and Science, 16 61-67.

Mohammadi V., Ghasemi-Varnamkhasti M., González L. (2017) Analytical measurements of ultrasound propagation in dairy products: A review. Trends in Food Science \&Technology, https://doi.org/10.1016/j.tifs.2016.12.004

Mostert F.J., Buys E.M. (2008) Hygiene by Design in Advanced Dairy Science and Technology (Britz, T.J., Robinson, R.K., ed.), Blackwell Publishing, Oxford, U.K. pp. 108-110.

Otero V., Becerril R., Santos J.A., Rodriguez-Calleja J.M., Nerin C., Garcia-Lopez M.L. (2014) Evaluation of two antimicrobial packaging films against Escherichia coli O157: H7 strains in vitro and during storage of a Spanish ripened sheep cheese (Zamorano). Food Control, 42 296-302.

Pantaleão I., Pintado M.M.E., Poças M.F.F. (2007) Evaluation of two packaging systems for regional cheese. Food Chemistry, 102 (2) $481-487$. https://doi.org/10.1016/j.foodchem.2006.05.058.

Patel H.G., Modha H., Ranganadham M. (2017) Packaging Of Dairy Products PDF Book. Available at: http://www.agrimoon.com/packaging-ofdairy-products-pdf-book/

Petrus R.R., Loiola C.G., Oliveira A.F. (2010) Microbiological Shelf Life of Pasteurized Milk in Bottle and Pouch, Journal of Food Science, 75 (1) 36-40.

Pinto M.S., Pires A.C.S., Sant Ana H.M.P., Soares N.F.F., Carvalho A.F. (2014) Influence of multilayer packaging and microfiltration process on milk shelf life. Food Packagning and Shelf Life, 1 (2) 151-159.

Poças M.F., Pintado M. (2010) Packaging and the shelf life of cheese. In Food Packaging and Shelf Life: A Pratical Guide (G.L. Robertson, Ed), Boca Raton, FL: CRC Press, pp. 103-125.

Rathore S., Desai M.P., Liew C.V., Chan L.W., Heng P.W.S. (2013) Microcapsulation of microbial cells. Journal of Food Engineering, $116369-381$. Ramos O.L., Pereira J.O., Silva S.I., Fernandes J.C., Franco M.I., Lopes-da-Silva J.A., Malcata F.X. (2012) Evaluation of antimicrobial edible coatings from a whey protein isolate base to improve the shelf life of cheese. Journal of Dairy Science, 95 6282-6292.

Ramonaityte D. T. (2001) Copper, zinc, tin and lead in canned evaporated milk, produced in Lithuania: the initial content and its change at storage. Food Additives and Contaminants, 18 (1) 31-37. https://doi.org/10.1080/02652030010008805

Reynolds P. (2012) Chinese dairy introduces a new kind of aseptic pouch. Packaging World, 678.

Robertson G.W. (2016) Packaging of Dairy Products. In: Food Packaging: Principles and Practice, Third Edition. CRC Press, Taylor\&Francis Group, pp. 509-540.

Khoshgozaran S., Hossein Azizi M., Bagheripoor-Fallah N. (2012) Evaluating the effect of modified atmosphere packaging on cheese characteristics: a review. Dairy Science and Technology, 92 1-24.

Sakare P., Bharimalla A.K., Dhakane-Lad J., Patil P.G. (2020) Development of Greaseproof Paper from Banana Pseudostem Fiber for Packaging of Butter. Journal of Natural Fibers, https://doi.org/10.1080/15440478.2019.1710652

Saffert A., Pieper G., Jetten J. (2009) Effect of package light transmittance on the vitamin content of milk, part 3: Fortified UHT low-fat milk. Packaging technology \& Science. 22 (1) 31-37.

Sanint-Eve A., Lévy C., Le Moigne M., Ducruet V., Souchon I. (2008) Quality changes in yogurt during storage in different packaging materials. Food Chemistry, 110 285-293.

Santana E.H.W., De Beloti V., Müller E.E., Ferreira M.A., Morales L.B.., Pereira M.S., Gusmão V.V. (2004) Milk contamination in different points of dairy process. ii) mesophilic, psychrotrophic and proteolytic microorganisms. Semina: Ciências Agrárias; Londrina, 25 349-358.

Santonicola S., Ferrante M.C., Murru N., Gallo P., Raffaelina Mercogliano R. (2019) Hot topic: Bisphenol A in cow milk and dietary exposure at the farm level. Journal of Dairy Science, 102 (2) 1007-1013. https://doi.org/10.3168/jds.2018-15338

Samaržija D., Šimun Z., Pogačić T. (2012) Psychritrophic bacteria and milk and dairy products quality. Mljekarstvo, 62 (2) 77-95.

Schuck P. (2011) DEHYDRATED DAIRY PRODUCTS; Milk Powder: Types and Manufacture in Encyclopedia of Dairy Sciences (Second Edition). Editor(s): John W. Fuquay,

Academic Press, 2011, Pages 108-116, ISBN 9780123744074, https://doi.org/10.1016/B978-0-12-374407-4.00121-7

Sinigaglia M., Bevilacqua A., Corbo M.R., Pati S., Del Nobile M.A. (2008) Use of active compounds for prolonging the shelf life of mozzarella 
cheese. International Dairy Journal, 18 624-630.

Spreafico C., Russo D. (2021) A sustainable cheese packaging survey involving scientific papers and patents. Journal of Cleaner Production, 293 126196. https://doi.org/10.1016/j.jclepro.2021.126196

Swartz W.E., Hartford C.G. (1999) Method for preventing spoilage, rancidity, and off-color by using a tricalcium phosphate ultraviolet light inhibitor. U.S. Patent No. 5,948,458. Washington, DC: U.S. Patent and Trademark Office.

Talwalker A., Miller C., Kailasapathy K., Nugyen M. (2004) Effect of packaging conditions and dissolved oxygen on the survival probiotic bacteria in yoghurt. International Journal of Food Science and Technology, 39 605-611.

Tripathi M.K., Gri S.K. (2014) Probiotic functional foods: Survival of probiotics during processing and storage. Journal of Functional Foods, 9 225-241.

Unalan I.U., Arcan I., Korel F., Yemenicioglu A. (2013) Application of active zein-based films with controlled release properties to control Listeria monocytogenes growth and lipid oxidation in fresh Kashar cheese. Innovative Food Science \& Emerging Technologies, $20208-214$.

Watnick P., Kolter R. (2000) Biofilm, City of Microbes. Journal of Bacteriology, 182 2675-2679. 